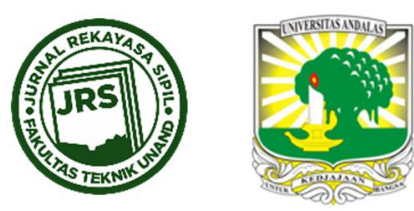

\title{
ANALISIS LIKUEFAKSI BERDASARKAN DATA CPT UNTUK PERANCANGAN PONDASI DI PESISIR PANTAI KABUPATEN KULON PROGO DIY
}

\author{
VEBRIAN ANGGARA ${ }^{1}$, FERRY FATNANTA ${ }^{1^{*}}$, MUHAMAD YUSA ${ }^{1}$ \\ ${ }^{1}$ Program Studi Teknik Sipil, Universitas Riau, Pekanbaru, Riau \\ *Corresponding author: $\triangle$ ferry.fatnanta@lecturer.unri.ac.id
}

Naskah diterima : 9 Maret 2020. Disetujui: 9 Juli 2020

\begin{abstract}
ABSTRAK
Yogyakarta Special Region (DIY) is an area that has a high level of seismic activity in Indonesia. This is due to various local faults near the land and its location adjacent to the subduction of the IndoAustralian and Eurasian plates. The proposed new airport is located on the coast in Kulon Progo Regency DIY. The location is dominated by the sands layer and it has high ground water levels which indicate the high potential of liquefaction. The site classes of the coast in Kulon Progo Regency is medium category (SD). Liquefaction analysis using the $\mathrm{PGA}_{M}$ value of $0.4 \mathrm{~g}$. Liquefaction has the potential to occur in soil layers 0 - 6 meters. The analysis shows for eartquake of $\geq 6.3 \mathrm{Mw}$ has a very high category of liquefaction. The analysis results has LPI $\geq 29.30$ for ground water conditions at the surface, and LPI $\geq 15.32$ for ground water conditions in depths of 3 meters. Estimated soil settlements of $19.7 \mathrm{~cm}$ for magnitude of $8.1 \mathrm{Mw}$ with ground water conditions at the surface. The use of shallow foundations at soil depths of $0-6$ meters is not recommended, unless a soil improvement method is used to eliminate the potential for liquefaction.
\end{abstract}

Kata kunci : liquefaction, LPI, magnitude, settlements

\section{PENDAHULUAN}

Daerah Istimewa Yogyakarta (DIY) merupakan kawasan yang secara tektonik memiliki tingkat aktivitas kegempaan yang tinggi di Indonesia. Aktivitas kegempaan ini terjadi dikarenakan lokasinya yang berdekatan dengan zona tumbukan lempeng Indo-australia dan Eurasia. DIY juga sangat rawan gempa bumi akibat aktivitas berbagai sesar lokal di daratan. Kondisi tektonik semacam ini menjadikan DIY dan sekitarnya sebagai kawasan seismik aktif dan kompleks.

Investigasi geoteknik dilakukan di kawasan pesisir pantai Kabupaten Kulon Progo DIY pada lahan 587.3 hektar. Investigasi geoteknik menggunakan CPT tipe mekanik (CPTm). Akan tetapi, untuk analisis potensi likuefaksi data mekanik perlu dikoreksi menjadi data elektrik (CPTe). Hal ini dikarenakan metode Boulanger and Idriss (2014) menggunakan data elektrik sebagai data analisisnya. Investigasi geoteknik menunjukan karakteristik lapisan

DOI : https://doi.org/10.25077/jrs.16.2.77-90.2020

Attribution-NonCommercial 4.0 International. Some rights reserved 
tanahnya merupakan pasir dan pasir berlanau. Maka dari itu, potensi likuefaksi perlu dianalisis di beberapa lahan tanahnya.

Potensi likuefaksi dianalisis menggunakan metode Boulanger and Idriss (2014). Analisis ini dilakukan untuk mengkaji potensi terjadinya likuefaksi pada variasi skala magnitudo gempa bumi tertentu (LPI) dan taksiran besar penurunan lapisan tanah. Sehingga, perancangan fondasi di pesisir pantai Kabupaten Kulon Progo DIY bisa diperhitungkan keamanannya.

\section{INVESTIGASI GEOTENIK DAN LIKUEFAKSI}

\subsection{Likuefaksi}

Likuefaksi adalah fenomena yang terjadi ketika tanah yang jenuh atau agak jenuh kehilangan kekuatan dan kekakuan akibat adanya tegangan, misalnya bersumber dari getaran gempa bumi atau perubahan ke tegangan lain secara mendadak, sehingga tanah yang padat berubah wujud menjadi cairan atau air berat. Kriteria umum yang menjadi syarat terjadinya likuefaksi yaitu tanah pasir lepas, bentuk butiran tanah pasir yang seragam, muka air tanah tinggi, dan gempa bumi umumnya dengan skala $\geq 6 \mathrm{Mw}$. Nasional (2008) memaparkan potensi terjadinya likuefaksi untuk lapisan tanah pasir mempunyai ciri muka air tanah kurang dari $10 \mathrm{~m}$ dan lapisan tanah pasir jenuh air kurang dari $20 \mathrm{~m}$.

\subsection{Sondir (Cone Penetration Test, CPT)}

CPT adalah investigasi geoteknik dengan melakukan penetrasi konus ke dalam tanah. Investigasi ini bertujuan untuk mengetahui daya dukung tanah berdasarkan parameter perlawanan tanah terhadap ujung konus $\left(\mathrm{q}_{\mathrm{c}}\right)$ dan hambatan lekat tanah dengan selubung konus $\left(f_{s}\right)$. Investigasi geoteknik CPT di lapangan terdiri dari CPT mekanik (CPTm) dan CPT elektrik (CPTe). Meisina (2017) telah melakukan studi perbedaan analisis likuefaksi terhadap kedua tipe CPT ini.

\subsubsection{Korelasi Data CPT dan Berat Isi Tanah}

Nilai berat isi tanah $(\gamma)$ dapat ditentukan berdasarkan nilai $\mathrm{q}_{\mathrm{c}}$ pengujian CPTe di lapangan. Robertson and Cabal (2010) memberikan persamaan empiris untuk mendapatkan nilai berat isi tanah.

$$
\gamma / \gamma_{\mathrm{w}}=0,27\left[\log \mathrm{R}_{\mathrm{f}}\right]+0,36\left[\log \left(\mathrm{q}_{\mathrm{t}} / \mathrm{p}_{\mathrm{a}}\right)\right]+1,236
$$

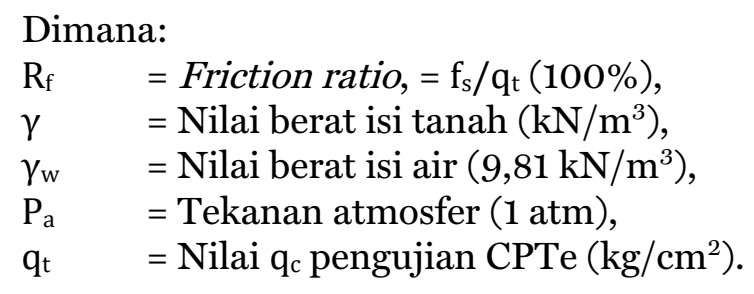

\subsubsection{Korelasi Data CPT dan Kecepatan Gelombang Geser}

Kecepatan gelombang geser (Vs) merupakan parameter dinamis tanah untuk menetukan klasifikasi situs tanah. Nilai Vs dapat ditentukan secara langsung dengan pengujian di lapangan atau melalui persamaan empiris. Ahmed (2017) menggunakan persamaan empiris korelasi data CPTe terhadap Vs yang diprakarsai oleh Wair (2012) berikut. 


$$
\begin{aligned}
& \mathrm{V}_{\mathrm{s}}=118.8 \log \mathrm{f}_{\mathrm{s}}+18.5 \\
& \mathrm{~V}_{\mathrm{s}}=2.41 \mathrm{q}_{\mathrm{t}}^{0.395} \mathrm{I}_{\mathrm{c}}^{0.124} \\
& \mathrm{~V}_{\mathrm{s}}=\left[10^{(0.55 \mathrm{c}+1.68)}\left(\frac{\mathrm{qt}_{\mathrm{t}}-\sigma \mathrm{V}}{\mathrm{Pa}_{\mathrm{a}}}\right)\right]^{0.5}
\end{aligned}
$$

\section{Dimana:}

$$
\begin{array}{ll}
f_{s} & =\text { Nilai local side friction, } \\
I_{c} & =\text { Indeks tipe perilaku tanah, } \\
P_{a} & =\text { Tekanan atmosfer, } \\
q_{t} & =\text { Nilai perlawanan ujung konus, } \\
V S & =\text { Kecepatan gelombang geser, } \\
\sigma_{\mathrm{v}} & =\text { Tegangan normal vertikal. }
\end{array}
$$

\subsubsection{Korelasi Data CPT dan N-SPT}

Nilai jumlah pukulan Standard Penetration Test (N-SPT) dapat ditentukan berdasarkan nilai $q_{c}$ pengujian CPTm di lapangan. Meyerhof (1956) memberikan persamaan empiris untuk mendapatkan nilai N-SPT untuk tanah pasir.

$$
\mathrm{q}_{\mathrm{c}}=4 \mathrm{~N}
$$

Dimana:

$\mathrm{q}_{\mathrm{c}} \quad=$ Nilai perlawanan konus $\left(\mathrm{kg} / \mathrm{cm}^{2}\right)$,

$\mathrm{N} \quad=$ Nilai jumlah pukulan pengujian SPT.

\subsection{Kelas Situs Tanah}

Kelas situs tanah berpengaruh terhadap analisa dampak likuefaksi pada lapisan tanah. Kelas situs tanah ditentukan berdasarkan parameter $\bar{v}_{s}, \bar{N}$, dan $\bar{s}_{u}$. Nasional (2012) memaparkan kriteria penentuan kelas situs tanah seperti yang ditunjukan pada Tabel 1. 
Tabel 1. Kelas Situs Tanah Berdasarkan Parameter $\bar{v}_{s}, \bar{N}$, dan $\bar{s}_{u \text {. }}$

\begin{tabular}{|c|c|c|c|}
\hline Kelas Situs & $\bar{v}_{s(\mathrm{~m} / \text { detik })}$ & $\bar{N}$ & $\bar{S}_{u(\mathrm{kPa})}$ \\
\hline SA (batuan keras) & $>1500$ & $\mathrm{~N} / \mathrm{A}$ & $\mathrm{N} / \mathrm{A}$ \\
\hline SB (batuan) & 750 sampai 1500 & $\mathrm{~N} / \mathrm{A}$ & $\mathrm{N} / \mathrm{A}$ \\
\hline 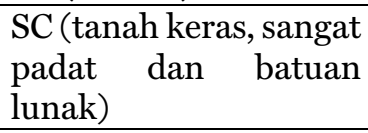 & 350 sampai 750 & $>50$ & $\geq 100$ \\
\hline SD (tanah sedang) & 175 sampai 350 & 15 sampai 50 & 50 sampai 100 \\
\hline SE (tanah lunak) & $<175$ & $<15$ & $<50$ \\
\hline & \multicolumn{3}{|c|}{$\begin{array}{l}\text { Atau setiap profil tanah yang mengandung } \\
\text { dengan karakteristik sebagai berikut: } \\
\text { 1. Indeks plastisitas, } \mathrm{PI}>20, \\
\text { 2. Kadar air, w } \geq 40 \% \text {, } \\
\text { 3. Kuat geser niralir } \bar{s}_{u<25 \mathrm{kPa} \text {. }}\end{array}$} \\
\hline $\begin{array}{l}\text { SF (tanah khusus, yang } \\
\text { membutuhkan } \\
\text { investigasi geoteknik } \\
\text { spesifik dan analisis } \\
\text { respons spesifik-situs } \\
\text { yang mengikuti 6.10.1) }\end{array}$ & \multicolumn{3}{|c|}{$\begin{array}{l}\text { Setiap profil lapisan tanah yang memiliki salah satu atau lebih } \\
\text { dari karakteristik berikut: } \\
\text { 1. Rawan dan berpotensi gagal atau runtuh akibat beban } \\
\text { gempa seperti mudah likuefaksi, lempung sangat } \\
\text { sensitif, tanah tersementasi lemah, } \\
\text { 2. Lempung kadar organik tinggi atau gambut, dengan } \\
\text { ketebalan, } \mathrm{H}>3 \mathrm{~m} \text {, } \\
\text { 3. Lempung dengan plastisitas sangat tinggi, dengan } \\
\text { ketebalan, } \mathrm{H}>7.5 \mathrm{~m} \text {, dengan indeks plastis, } P I>75 \text {, } \\
\text { 4. Lempung lunak, dengan ketebalan } \mathrm{H}>35 \mathrm{~m} \text { dengan } \\
\mathrm{Su}<50 \mathrm{kPa} \text {. }\end{array}$} \\
\hline
\end{tabular}

Catatan: $\mathrm{N} / \mathrm{A}=$ Tidak dapat dipakai.

\subsection{Metode Boulanger dan Idriss 2014}

Metode Boulanger and Idriss (2014) adalah pendekatan berbasis tegangan untuk mengevaluasi potensi likuefaksi. Metode ini membandingkan CSR (Cyclic Stress Ratio) yang diinduksi gempa bumi dengan CRR (Cyclic Resistance Ratio) dari tanah. CRR tanah berkorelasi dengan parameter in-situ seperti ketahanan CPT atau kecepatan gelombang geser (Vs). Pendekatan berbasis tegangan dapat dijelaskan pada prosedur analisis.

\subsubsection{CSR yang Diinduksi Gempa Bumi}

CSR yang diinduksi gempa bumi, pada kedalaman tertentu (z), dalam profil tanah, biasanya dinyatakan sebagai nilai representatif (nilai seragam yang setara) yang setara dengan $65 \%$ dari rasio siklik tegangan geser maksimum.

$$
\operatorname{CSR}_{\mathrm{M},{ }^{\prime} \mathrm{v}}=0.65 \frac{\sigma \mathrm{v}}{\sigma^{\prime} \mathrm{v}} \frac{\mathrm{amax}}{\mathrm{g}} \mathrm{r}_{\mathrm{d}}
$$

Dimana:

$\sigma_{\mathrm{v}} \quad=$ Tegangan total vertikal pada kedalaman $\mathrm{z}$,

$a_{\max } / \mathrm{g}=$ Akselerasi horizontal maksimum (sebagai fraksi gravitasi) pada permukaan tanah,

$\mathrm{r}_{\mathrm{d}} \quad=$ Faktor reduksi tegangan geser yang memperhitungkan dinamis respons dari profil tanah. 


\subsubsection{CSR dan Resistansi CPT}

CRR berkorelasi dengan CPT dalam penerapan koreksi terhadap tegangan overburden. Data CPT dikoreksi pada tahanan ujung $\left(\mathrm{q}_{\mathrm{c}}\right)$ untuk efek area ujung yang tidak sama. Boulanger and Idriss (2014) memberikan persamaan sebagai,

$$
\begin{aligned}
& \mathrm{CRR}_{\mathrm{M}, \sigma^{\prime} \mathrm{v}}=\mathrm{CRR}_{\mathrm{M}=7.5, \sigma^{\prime}=1} \cdot \mathrm{MSF} \cdot \mathrm{K}_{\sigma} \\
& \mathrm{CRR}_{\mathrm{M}=7.5, \sigma^{\prime}=1}=\exp \left[\frac{\mathrm{qc} 1 \mathrm{Ncs}}{113}+\left(\frac{\mathrm{qc} 1 \mathrm{Ncs}}{1000}\right)^{2}-\left(\frac{\mathrm{qc} 1 \mathrm{Ncs}}{140}\right)^{3}+\left(\frac{\mathrm{qc} 1 \mathrm{Ncs}}{137}\right)^{4}-2.80\right]
\end{aligned}
$$

Dimana:

$\mathrm{K}_{\sigma} \quad=$ Faktor koreksi overbourden,

MSF = Magnitude scale factor,

$\mathrm{q}_{\mathrm{c} 1 \mathrm{Ncs}}=$ Resistansi penetrasi yang akan diperoleh dalam pasir bersih.

\subsubsection{Faktor Aan terhadap Likuefaksi (FS)}

Untuk menentukan nilai kemanan suatu lapisan tanah terhadap bahaya likuefaksi, maka diberikan persamaan sebagai berikut:

$$
\mathrm{FS}=\frac{\mathrm{CRR}}{\mathrm{CSR}}
$$

Dimana:

CRR = Rasio tahanan siklik (Cyclic resistance ratio),

CSR = Rasio tegangan siklik (Cyclic stress ratio),

FS $\quad=$ Faktor keamanan (Factor of safety).

\subsubsection{Indeks Potensi Likuefaksi (Liquefaction Potential Index, LPI)}

LPI adalah suatu indeks yang digunakan untuk estimasi potensi likuefaksi yang menyebabkan kerusakan fondasi. Iwasaki (1978) memberikan nilai LPI untuk tinjauan profil tanah kedalaman 20 meter.

$$
\begin{aligned}
& \text { LPI }=\int_{0}^{20 \mathrm{~m}} \mathrm{Fw}(\mathrm{z}) \mathrm{dz} \\
& \mathrm{F} \quad=1-\mathrm{FS} \quad \text { untuk } \mathrm{FS} \leq 1 \text {, } \\
& \mathrm{F} \quad=0 \quad \text { untuk FS }>1 \text {, } \\
& \mathrm{w}(\mathrm{z}) \quad=10-0,5 \mathrm{z}
\end{aligned}
$$

Dimana:

$\mathrm{w}(\mathrm{z})=$ Fungsi bobot (weighting) yang bergantung pada kedalaman, $\mathrm{z} \quad=$ Kedalaman lapisan $\operatorname{tanah}(\mathrm{m})$.

Untuk profil tanah kurang dari kedalaman 20 meter, LPI dapat dihitung menggunakan persamaan Luna and Frost (1998).

$$
\mathrm{LPI}=\sum_{\mathrm{i}=1}^{\mathrm{n}} \mathrm{wi} . \mathrm{Fi} . \mathrm{Hi}
$$




$$
\begin{array}{lll}
\mathrm{F}_{\mathrm{i}} & =1-\mathrm{FS}_{\mathrm{i}} & \text { untuk } F S_{\mathrm{i}} \leq 1, \\
\mathrm{~F}_{\mathrm{i}} & =0 & \text { untuk FS } \mathrm{i}>1, \\
\mathrm{~W}_{\mathrm{i}} & =10-0,5 \mathrm{zi}_{\mathrm{i}} &
\end{array}
$$

Dimana:

$\mathrm{H}_{\mathrm{i}} \quad=$ Ketebalan lapisan tanah ke- $i(\mathrm{~m})$,

$\mathrm{n} \quad=$ Nomor lapisan tanah ke- $i$,

$\mathrm{w}_{\mathrm{i}} \quad$ Fungsi bobot (weighting) yang bergantung pada kedalaman,

$\mathrm{z}_{\mathrm{i}} \quad=$ Kedalaman lapisan tanah ke- $i(\mathrm{~m})$.

Menurut Iwasaki (1978) dan Luna and Frost (1998) klasifikasi LPI terhadap resiko potensi likuefaksi tertera pada Tabel 2. Dixit (2012) telah menggunakan kedua klasifikasi ini untuk menentukan potensi likuefaksi di kota mumbai.

Tabel 2. Potensi Likuefaksi Berdasarkan Nilai LPI.

\begin{tabular}{ccc}
\multirow{2}{*}{ LPI } & \multicolumn{2}{c}{ Potensi Likuefaksi } \\
\cline { 2 - 3 } & $\begin{array}{c}\text { Iwasaki et al. } \\
(\mathbf{1 9 7 8 )}\end{array}$ & $\begin{array}{c}\text { Luna dan Frost } \\
(\text { 1998) }\end{array}$ \\
\hline LPI $=0$ & Sangat Rendah & Little to none \\
\hline $0<$ LPI $<5$ & Rendah & Minor \\
\hline $5 \leq$ LPI $\leq 15$ & Tinggi & Moderate \\
\hline LPI $>15$ & Sangat Tinggi & Major \\
\hline
\end{tabular}

\subsubsection{Penurunan Tanah}

Likuefaksi akan menjadi masalah serius ketika menyebabkan penurunan permukaan tanah selama goncangan gempa bumi. Penurunan permukaan tanah terjadi pada regangan yang relatif kecil (small-strain) setelah likuefaksi (post liquefaction). Zhang (2002) mengemukakan hubungan nilai tahanan ujung seismik dan regangan volumetrik untuk beragam faktor keamanan dari hasil analisis terhadap potensi likuefaksi. Nilai regangan volumetrik sebagai akibat disipasi tekanan air pori saat goncangan gempa akan digunakan untuk penghitungan penurunan permukaan tanah.

$$
S=\int_{0}^{z} \varepsilon_{v} d z=\sum_{i=1}^{j} \varepsilon_{v i} . \Delta z i
$$

Dimana:

$\varepsilon_{\mathrm{vi}} \quad=$ Regangan volumetrik pasca likuefaksi pada lapisan tanah ke- $i$,

$\Delta \mathrm{zi} \quad=$ Tebal lapisan tanah ke-i.

Secara empirik, besarnya regangan vertikal seismik sebagai fungsi dari faktor aman dan nilai tahanan seperti yang tertera pada Tabel 3. Persamaan empirik regangan seismik selanjutnya dipakai untuk menentukan besar penurunan yang terjadi di setiap lapisan tanah jenuh air yang mengalami likuefaksi.

Tabel 3. Persamaan Empirik Regangan Seismik (Zhang, 2002)

\begin{tabular}{ccc}
\hline $\begin{array}{c}\text { Faktor Aman } \\
\text { (FS) }\end{array}$ & $\begin{array}{c}\text { Nilai Tahanan Ujung } \\
\text { Seismik }\left(\mathrm{q}_{\mathrm{c} 1 \mathrm{~N}}\right)_{\mathrm{cs}}\end{array}$ & $\begin{array}{c}\text { Regangan } \\
\text { Seismik }\left(\varepsilon_{\mathrm{v}}\right)\end{array}$ \\
\hline$\leq 0.5$ & $33 \leq\left(\mathrm{q}_{\mathrm{clN}}\right)_{\mathrm{cs}} \leq 200$ & $102\left(\mathrm{q}_{\mathrm{clN}}\right)_{\mathrm{cs}}{ }^{-0.82}$ \\
\hline 0.6 & $33 \leq\left(\mathrm{q}_{\mathrm{clN}}\right)_{\mathrm{cs}} \leq 147$ & $102\left(\mathrm{q}_{\mathrm{clN}}\right)_{\mathrm{cs}}{ }^{-0.82}$ \\
\hline
\end{tabular}




\begin{tabular}{|c|c|c|}
\hline $\begin{array}{l}\text { Faktor Aman } \\
\text { (FS) }\end{array}$ & $\begin{array}{l}\text { Nilai Tahanan Ujung } \\
\text { Seismik }\left(q_{c 1 N}\right)_{c s}\end{array}$ & $\begin{array}{c}\text { Regangan } \\
\text { Seismik }\left(\varepsilon_{\mathrm{v}}\right)\end{array}$ \\
\hline & $147 \leq\left(\mathrm{q}_{\mathrm{c} 1 \mathrm{~N}}\right)_{\mathrm{cs}} \leq 200$ & $2411\left(\mathrm{q}_{\mathrm{c} 1 \mathrm{~N}}\right)_{\mathrm{cs}}{ }^{-1.45}$ \\
\hline \multirow{2}{*}{0.7} & $33 \leq\left(\mathrm{q}_{\mathrm{c1N}}\right)_{\mathrm{cs}} \leq 110$ & $102\left(\mathrm{q}_{\mathrm{c} 1 \mathrm{~N}}\right)_{\mathrm{cs}}{ }^{-0.82}$ \\
\hline & $110 \leq\left(\mathrm{q}_{\mathrm{clN}}\right)_{\mathrm{cs}} \leq 200$ & $1701\left(\mathrm{q}_{\mathrm{c} 1 \mathrm{~N}}\right)_{\mathrm{cs}}{ }^{-1.42}$ \\
\hline \multirow{2}{*}{0.8} & $33 \leq\left(\mathrm{q}_{\mathrm{c} 1 \mathrm{~N}}\right)_{\mathrm{cs}} \leq 80$ & $102\left(\mathrm{q}_{\mathrm{c} 1 \mathrm{~N}}\right)_{\mathrm{cs}}^{-0.82}$ \\
\hline & $80 \leq\left(q_{\mathrm{clN}}\right)_{\mathrm{cs}} \leq 200$ & $1690\left(\mathrm{q}_{\mathrm{c} 1 \mathrm{~N}}\right)_{\mathrm{cs}}{ }^{-1.46}$ \\
\hline \multirow{2}{*}{0.9} & $33 \leq\left(\mathrm{q}_{\mathrm{clN}}\right)_{\mathrm{cs}} \leq 60$ & $102\left(\mathrm{q}_{\mathrm{c} 1 \mathrm{~N}}\right)_{\mathrm{cs}}{ }^{-0.82}$ \\
\hline & $60 \leq\left(q_{\mathrm{c} 1 N}\right)_{\mathrm{cs}} \leq 200$ & $1430\left(\mathrm{q}_{\mathrm{c} 1 \mathrm{~N}}\right)_{\mathrm{cs}}{ }^{-1.48}$ \\
\hline 1.0 & $33 \leq\left(\mathrm{q}_{\mathrm{clN}}\right)_{\mathrm{cs}} \leq 200$ & $64\left(\mathrm{q}_{\mathrm{c} 1 \mathrm{~N}}\right)_{\mathrm{cs}}{ }^{-0.93}$ \\
\hline 1.1 & $33 \leq\left(\mathrm{q}_{\mathrm{c} 1 \mathrm{~N}}\right)_{\mathrm{cs}} \leq 200$ & $11\left(\mathrm{q}_{\mathrm{clN}}\right)_{\mathrm{cs}}{ }^{-0.65}$ \\
\hline 1.2 & $33 \leq\left(\mathrm{q}_{\mathrm{c} 1 \mathrm{~N}}\right)_{\mathrm{cs}} \leq 200$ & $9.7\left(\mathrm{q}_{\mathrm{c} 1 \mathrm{~N}}\right)_{\mathrm{cs}}{ }^{-0.69}$ \\
\hline 1.3 & $33 \leq\left(\mathrm{q}_{\mathrm{clN}}\right)_{\mathrm{cs}} \leq 200$ & $7.6\left(\mathrm{q}_{\mathrm{clN}}\right)_{\mathrm{cs}}{ }^{-0.71}$ \\
\hline 2.0 & $33 \leq\left(\mathrm{q}_{\mathrm{clN}}\right)_{\mathrm{cs}} \leq 200$ & 0 \\
\hline
\end{tabular}

\section{METODOLOGI PENELITIAN}

Penelitian analisis potensi likuefaksi menggunakan data investigasi geoteknik bawah permukaan berupa data CPT. Selain data tanah, data gempa wilayah juga dipakai sebagai energi pemicu likuefaksi. Data gempa wilayah yang dipakai adalah data kegempaan DIY. Data gempa bumi yang dipakai berupa magnitudo dan PGA yang terambatkan ke permukaan tanah $\left(\mathrm{PGA}_{\mathrm{M}}\right)$. Metode Boulanger and Idriss (2014) adalah salah satu cara untuk mengetahui ketahanan atau kekuatan lapisan tanah terhadap potensi likuefaksi. Penentuan potensi likuefaksi yaitu berdasarkan besarnya data CPTe dan kegempaan. Dari korelasi hubungan data CPTe dan gempa akan didapatkan parameter kekuatan tanah menahan likuefaksi akibat gempa (CRR), tegangan geser tanah akibat gempa (CSR), dan Factor of Safety (FS). Nilai FS yang digunakan dalam penelitian ini menggunakan batasan sebesar FS > 1 menunjukan lapisan tanah tidak berpotensi terjadi likuefaksi, sedangkan nilai FS $<1$ menunjukan lapisan tanah berpotensi likuefaksi.

\subsection{Lokasi Penelitian}

Lokasi penelitian berada di kawasan pesisir pantai di Kabupaten Kulon Progo, Provinsi Daerah Istimewa Yogyakarta. Lokasi pengujian seperti terlihat pada Gambar 1.

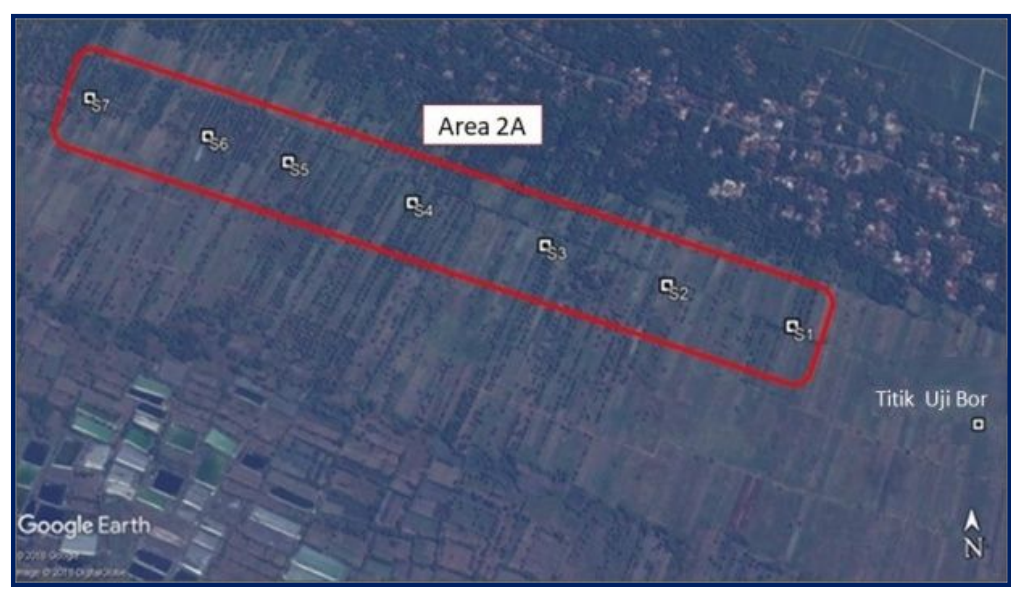

Gambar 1. Lokasi Pengujian CPTm dan Boring di Kawasan Pesisir Pantai Kabupaten Kulon Progo DIY. 


\subsection{Data Penelitian}

\subsubsection{Data CPT}

Data CPT yang digunakan pada analisis merupakan data sekunder dari Survey Topografi \& Soil Investigation DPPU Kulon Progo yang dilakukan oleh PT. Surveyor Indonesia. Pengujian CPT menggunakan tipe CPTm dengan jumlah pengujian sebanyak tujuh titik. Data $\mathrm{q}_{\mathrm{c}}$ dan $\mathrm{R}_{\mathrm{f}}$ pengujian CPTm dapat terlihat pada Gambar 2.

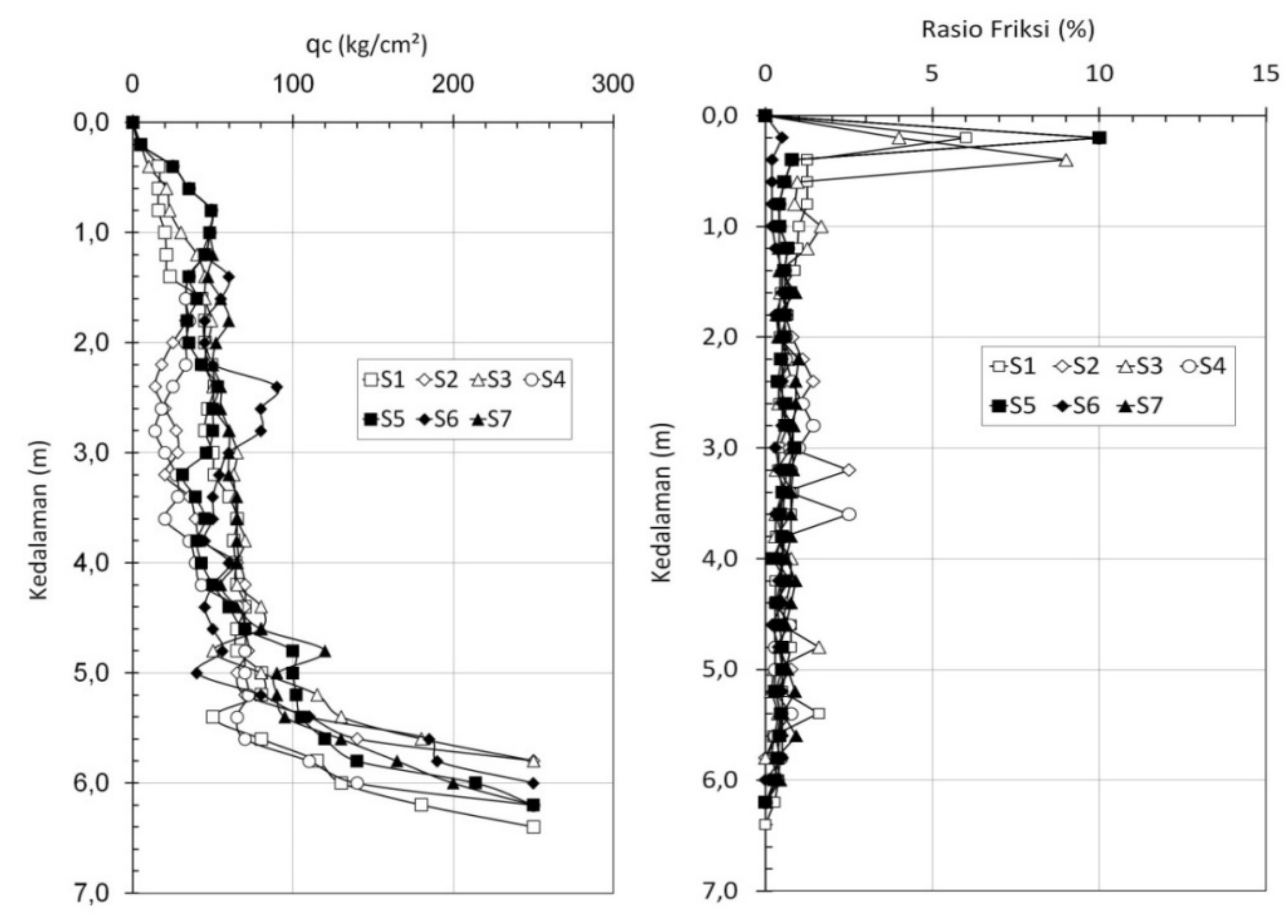

Gambar 2. Data $\mathrm{q}_{\mathrm{c}}$ dan $\mathrm{R}_{\mathrm{f}}$ Pengujian CPTm.

\subsubsection{Data Sifat Fisis Tanah}

Uji boring telah dilakukan pada kawasan pesisir pantai di Kabupaten Kulon Progo DIY. Uji boring dilakukan pada satu titik dengan kedalaman lapisan $40 \mathrm{~m}$. Sampel tanah hasil boring kemudian dilakukan uji labaratorium untuk mendapatkan data sifat fisis tanah. Lapisan tanah lebih dominan kandungan pasir, kandungan butiran halus, kandungan kerikil sangat sedikit, dan kondisi muka air tanah berada di kedalaman 3 meter. 

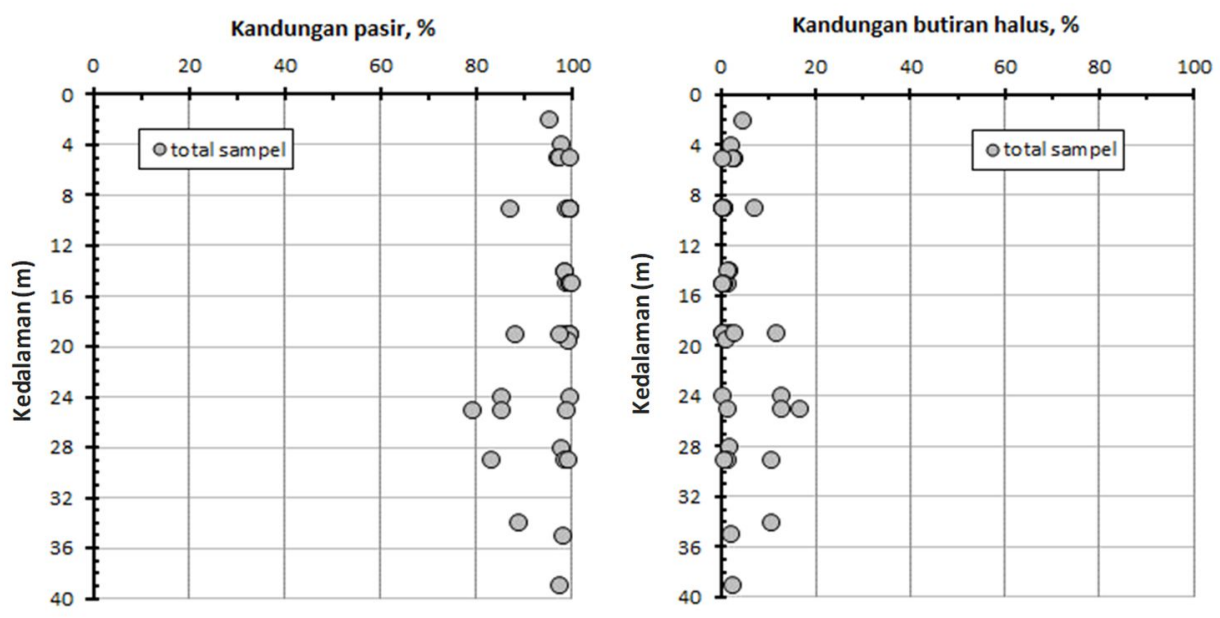

Gambar 3. Persentase Kandungan Butiran Tanah Hasil Uji Boring.

\section{HASIL DAN PEMBAHASAN}

\subsection{Analisis Kelas Situs Tanah}

Kelas situs tanah di kawasan pesisir pantai Kabupaten Kulon Progo DIY ditentukan berdasarkan data CPTe yang dikorelasikan dengan parameter $\bar{v}_{s}$ dan $\bar{N}$. Hasil analisis ditampilkan pada Tabel 4.

Tabel 4. Kelas Situs Tanah Berdasarkan Parameter $\bar{v}_{s}$ dan $\bar{N}$.

\begin{tabular}{ccccc}
\hline $\begin{array}{c}\text { Titik } \\
\text { CPT }\end{array}$ & $\begin{array}{c}\text { Kedalaman } \\
(\mathrm{m})\end{array}$ & $\begin{array}{c}\bar{v}_{s} \\
(\mathrm{~m} / \text { detik }\end{array}$ & $\bar{N}$ & Kelas Situs \\
\hline S1 & $0-30$ & 177,79 & 27 & SD (Tanah Sedang) \\
\hline S2 & $0-30$ & 175,01 & 26 & SD (Tanah Sedang) \\
\hline S3 & $0-30$ & 192,67 & 29 & SD (Tanah Sedang) \\
\hline S4 & $0-30$ & 175,23 & 25 & SD (Tanah Sedang) \\
\hline S5 & $0-30$ & 180,60 & 30 & SD (Tanah Sedang) \\
\hline S6 & $0-30$ & 182,18 & 31 & SD (Tanah Sedang) \\
\hline S7 & $0-30$ & 192,66 & 32 & SD (Tanah Sedang) \\
\hline
\end{tabular}

\subsection{Analisis Nilai $P_{G A}$}

Nilai PGA $_{M}$ merupakan nilai PGA yang telah terambatkan ke permukaan tanah. Nilai PGA yang ditinjau tertuju pada wilayah Kabupaten Kulon Progo DIY.

Tabel 5. Nilai $\mathrm{PGA}_{M}$ Daerah Istimewa Yogyakarta.

\begin{tabular}{cccc}
\hline Sumber & PGA & F $_{\text {PGA }}$ & PGA $_{\mathbf{M}}$ \\
\hline Peta Sumber dan Bahaya Gempa Indonesia 2017 & 0,4 & 1,0 & 0,4 \\
& & & \\
\hline
\end{tabular}




\subsection{Analisis Nilai FS}

Analisis FS dilakukan pada tanah kategori sedang dengan batasan sampai kedalaman 6,4 meter. Hasil analisis potensi likuefaksi menunjukan lapisan tanah di kedalaman $\geq 6$ meter sudah aman terhadap bahaya likuefaksi untuk setiap data CPTe. Khusus pada gempa skala magnitudo $5 \mathrm{Mw}$ kondisi muka air tanah di kedalaman 3 meter, ada beberapa lapisan yang masih aman terhadap likuefaksi di rentang kedalaman $0-6,4$ meter. Hasil analisis nilai FS untuk masing-masing data CPTe ditunjukan pada Gambar 4 sampai Gambar 7.

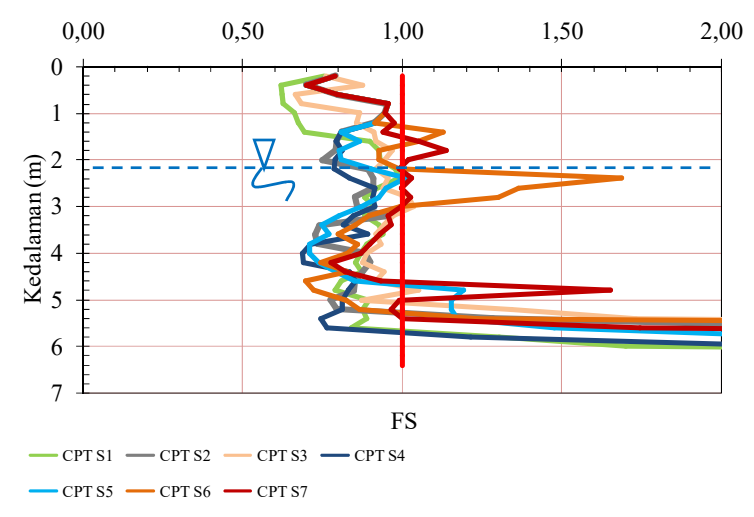

(a) Muka Air Tanah di Kedalaman 3 meter.

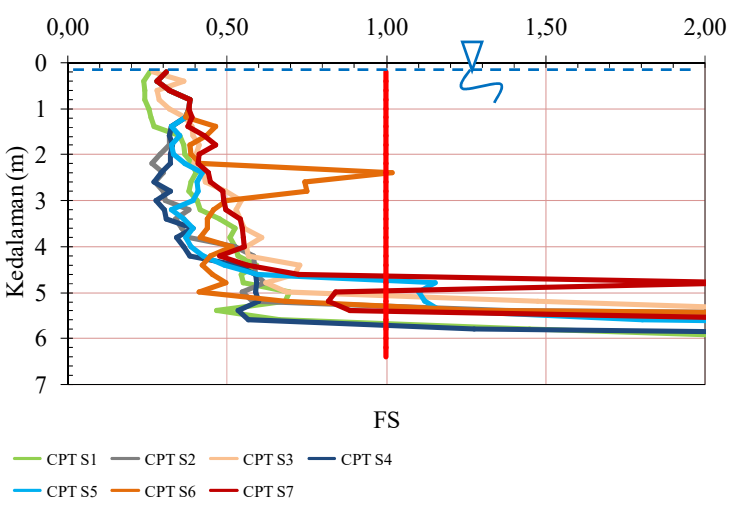

(b) Muka Air Tanah di Permukaan.

Gambar 4. Hasil Analisis Nilai FS pada Magnitudo $5 \mathrm{Mw}$.

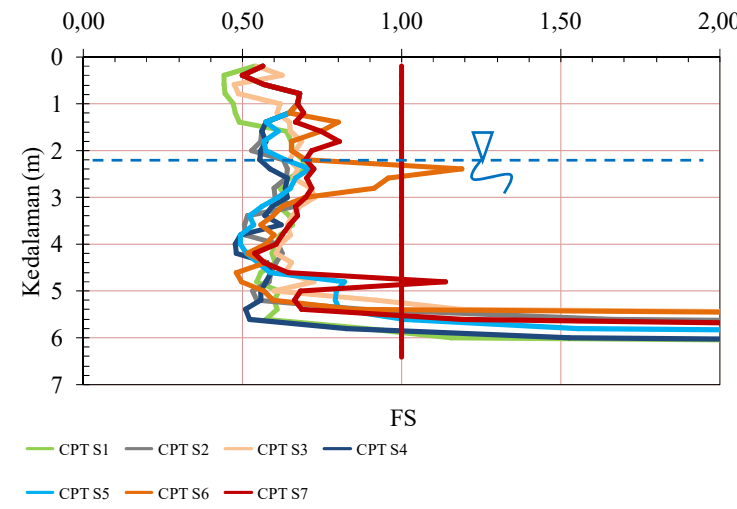

(a) Muka Air Tanah di Kedalaman 3 meter.

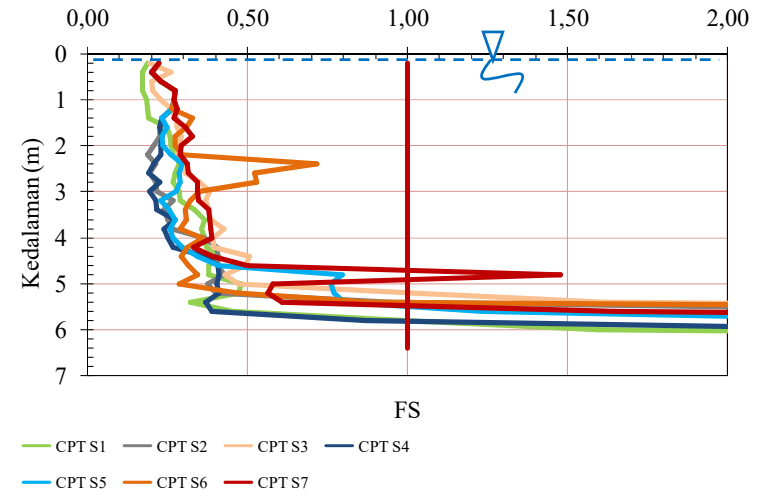

(b) Muka Air Tanah di Permukaan.

Gambar 5. Hasil Analisis Nilai FS pada Magnitudo 6,3 Mw. 


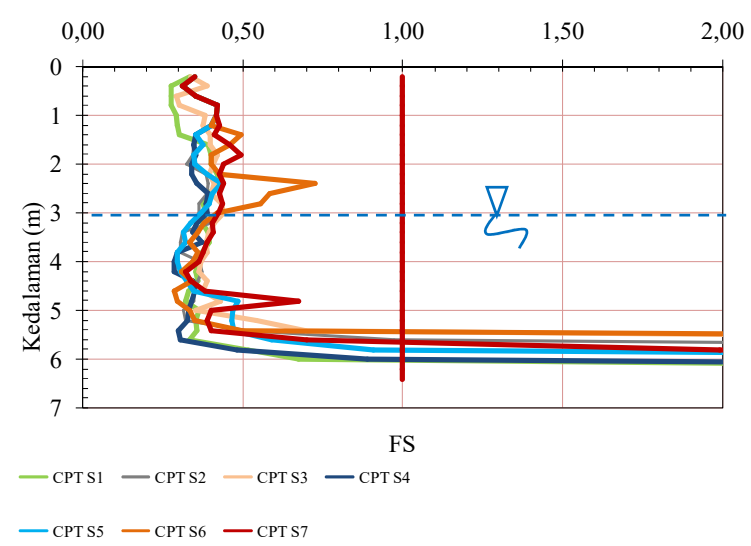

(a) Muka Air Tanah di Kedalaman 3 meter.

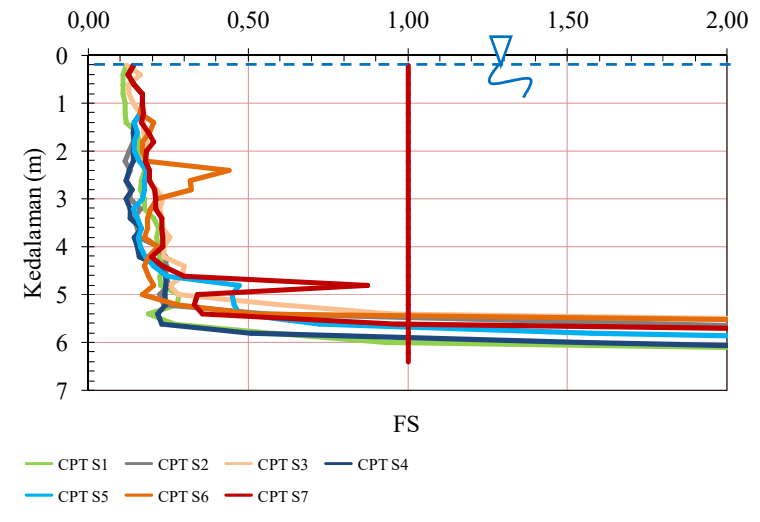

(b) Muka Air Tanah di Permukaan.

Gambar 6. Hasil Analisis Nilai FS pada Magnitudo 8,1 Mw.

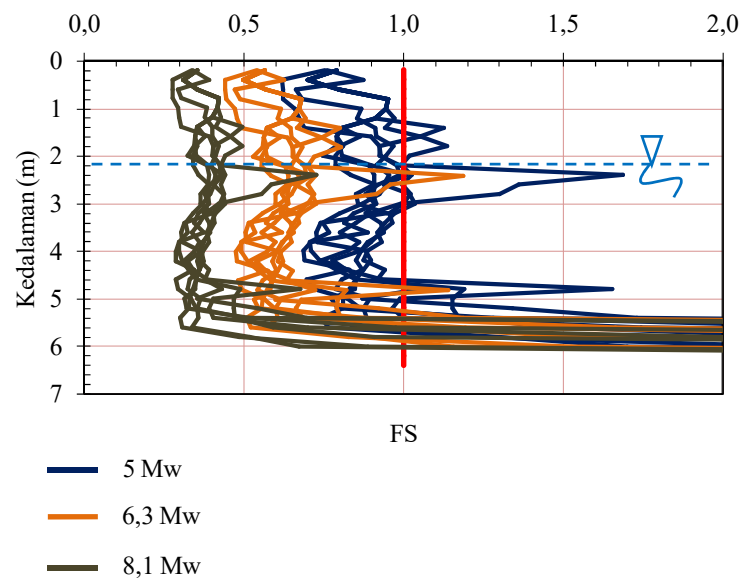

(a) Muka Air Tanah di Kedalaman 3 meter.

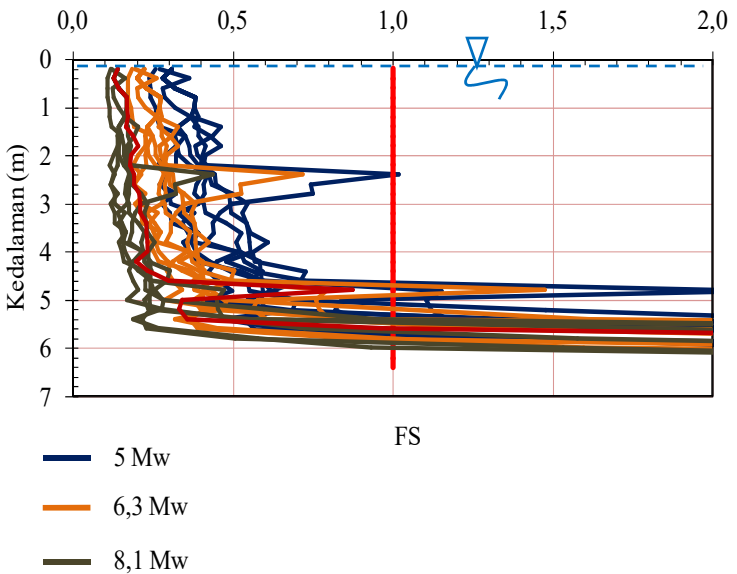

(b) Muka Air Tanah di Permukaan.

Gambar 7. Perbandingan Hasil Analisis Nilai FS pada Variasi Magnitudo Gempa.

\subsubsection{Analisis Indeks Potensi Likuefaksi (LPI)}

LPI dianalisis bedasarkan nilai FS yang dimiliki setiap lapisan tanah. Jumlah kedalaman lapisan tanah pasir $<20$ meter. Luna and Frost (1998) digunakan sebagai penentuan potensi likuefaksi.

Tabel 6. Potensi Likuefaksi pada Kondisi Muka Air Tanah di Kedalaman 3 Meter.

\begin{tabular}{|c|c|c|c|c|c|c|}
\hline \multirow{3}{*}{$\begin{array}{c}\text { Data } \\
\text { CPT } \\
\text { e }\end{array}$} & \multicolumn{6}{|c|}{ Magnitudo Gempa } \\
\hline & \multicolumn{2}{|c|}{$5 \mathrm{Mw}$} & \multicolumn{2}{|c|}{$6,3 \mathrm{Mw}$} & \multicolumn{2}{|c|}{$8,1 \mathrm{Mw}$} \\
\hline & LPI & Potensi & LPI & Potensi & LPI & Potensi \\
\hline $\mathrm{S} 1$ & 8,18 & Tinggi & 20,20 & $\begin{array}{l}\text { Sangat } \\
\text { Tinggi }\end{array}$ & 32,12 & $\begin{array}{l}\text { Sangat } \\
\text { Tinggi }\end{array}$ \\
\hline $\mathrm{S} 2$ & 7,45 & Tinggi & 18,77 & $\begin{array}{l}\text { Sangat } \\
\text { Tinggi }\end{array}$ & 29,65 & $\begin{array}{l}\text { Sangat } \\
\text { Tinggi }\end{array}$ \\
\hline S3 & 4,53 & Rendah & 16,11 & $\begin{array}{l}\text { Sangat } \\
\text { Tinggi }\end{array}$ & 27,86 & $\begin{array}{l}\text { Sangat } \\
\text { Tinggi }\end{array}$ \\
\hline
\end{tabular}




\begin{tabular}{ccccccc}
\hline \multirow{2}{*}{$\begin{array}{c}\text { Data } \\
\text { CPT } \\
\text { e }\end{array}$} & \multicolumn{6}{c}{ Magnitudo Gempa } \\
\cline { 2 - 7 } & LPI & Potensi & LPI & Potensi & LPI & Potensi \\
\hline S4 & 8,64 & Tinggi & 20,58 & $\begin{array}{c}\text { Sangat } \\
\text { Tinggi }\end{array}$ & 32,02 & $\begin{array}{c}\text { Sangat } \\
\text { Tinggi }\end{array}$ \\
\hline S5 & 6,77 & Tinggi & 17,89 & $\begin{array}{c}\text { Sangat } \\
\text { Tinggi }\end{array}$ & 29,81 & $\begin{array}{c}\text { Sangat } \\
\text { Tinggi }\end{array}$ \\
\hline S6 & 5,38 & Tinggi & 15,80 & $\begin{array}{c}\text { Sangat } \\
\text { Tinggi }\end{array}$ & 27,59 & $\begin{array}{c}\text { Sangat } \\
\text { Tinggi }\end{array}$ \\
\hline S7 & 3,25 & Rendah & 15,32 & $\begin{array}{c}\text { Sangat } \\
\text { Tinggi }\end{array}$ & 27,83 & $\begin{array}{c}\text { Sangat } \\
\text { Tinggi }\end{array}$ \\
\hline
\end{tabular}

Tabel 7. Potensi Likuefaksi pada Kondisi Muka Air Tanah di Permukaan.

\begin{tabular}{ccccccc}
\hline \multirow{2}{*}{$\begin{array}{c}\text { Data } \\
\text { CPT } \\
\text { e }\end{array}$} & \multicolumn{5}{c}{ Magnitudo Gempa } \\
\cline { 2 - 7 } & LPI & Potensi & LPI & Potensi & LPI & Potensi \\
\hline S1 & 27,91 & Sangat Tinggi & 33,94 & $\begin{array}{c}\text { Sangat } \\
\text { Tinggi }\end{array}$ & 40,14 & $\begin{array}{c}\text { Sangat } \\
\text { Tinggi }\end{array}$ \\
\hline S2 & 27,61 & Sangat Tinggi & 32,88 & $\begin{array}{c}\text { Sangat } \\
\text { Tinggi }\end{array}$ & 38,24 & $\begin{array}{c}\text { Sangat } \\
\text { Tinggi }\end{array}$ \\
\hline S3 & 23,25 & Sangat Tinggi & 29,30 & $\begin{array}{c}\text { Sangat } \\
\text { Tinggi }\end{array}$ & 35,55 & $\begin{array}{c}\text { Sangat } \\
\text { Tinggi }\end{array}$ \\
\hline S4 & 29,55 & Sangat Tinggi & 35,23 & $\begin{array}{c}\text { Sangat } \\
\text { Tinggi }\end{array}$ & 40,81 & $\begin{array}{c}\text { Sangat } \\
\text { Tinggi }\end{array}$ \\
\hline S5 & 25,23 & Sangat Tinggi & 31,05 & $\begin{array}{c}\text { Sangat } \\
\text { Tinggi }\end{array}$ & 37,54 & $\begin{array}{c}\text { Sangat } \\
\text { Tinggi }\end{array}$ \\
\hline S6 & 23,87 & Sangat Tinggi & 30,30 & $\begin{array}{c}\text { Sangat } \\
\text { Tinggi }\end{array}$ & 36,66 & $\begin{array}{c}\text { Sangat } \\
\text { Tinggi }\end{array}$ \\
\hline S7 & 22,96 & Sangat Tinggi & 29,54 & $\begin{array}{c}\text { Sangat } \\
\text { Tinggi }\end{array}$ & 35,84 & $\begin{array}{c}\text { Sangat } \\
\text { Tinggi }\end{array}$ \\
\hline
\end{tabular}

Hasil analisis LPI (Tabel 6 \& 7) menunjukan bahwa kawasan pesisir pantai di Kabupaten Kulon Progo DIY berpotensi sangat tinggi mengalami likuefaksi pada gempa dengan skala magnitudo $\geq 6,3 \mathrm{Mw}$. Likuefaksi berpotensi terjadi pada kedalaman lapisan $0-6$ meter. Maka dari itu, perlu perbaikan tanah untuk antisipasi bahaya likuefaksi di kawasan tersebut. Untuk bangunan gedung, pembangunan konstruksi fondasi disarankan mempunyai kedalaman melebihi 6 meter.

\subsubsection{Analisis Penurunan Tanah}

Analisis penurunan tanah akibat likuefaksi menggunakan metode Zhang (2002). Penurunan tanah dianalisis menggunakan besaran nilai regangan seismik $\left(\varepsilon_{\mathrm{v}}\right)$ yang dikorelasikan dari nilai FS.

Tabel 8. Penurunan Tanah pada Variasi Magnitudo dan Muka Air Tanah.

\begin{tabular}{|c|c|c|c|c|c|c|}
\hline \multirow{3}{*}{$\begin{array}{l}\text { Data } \\
\text { CPTe }\end{array}$} & \multicolumn{6}{|c|}{ Penurunan Tanah $(\mathrm{cm})$} \\
\hline & \multicolumn{3}{|c|}{ m.a.t di Kedalaman 3 Meter } & \multicolumn{3}{|c|}{ m.a.t di Permukaan } \\
\hline & $5 \mathrm{Mw}$ & $6,3 \mathrm{Mw}$ & $8,1 \mathrm{Mw}$ & $5 \mathrm{Mw}$ & $6,3 \mathrm{Mw}$ & $8,1 \mathrm{Mw}$ \\
\hline S1 & 5,8 & 7,6 & 8,0 & 18,8 & 19,0 & 19,3 \\
\hline S2 & 6,2 & 7,2 & 7,5 & 18,0 & 18,2 & 18,4 \\
\hline S3 & 3,4 & 5,8 & 6,2 & 14,4 & 14,6 & 14,9 \\
\hline
\end{tabular}




\begin{tabular}{|c|c|c|c|c|c|c|}
\hline \multirow{3}{*}{$\begin{array}{l}\text { Data } \\
\text { CPTe }\end{array}$} & \multicolumn{6}{|c|}{ Penurunan Tanah (cm) } \\
\hline & \multicolumn{3}{|c|}{ m.a.t di Kedalaman 3 Meter } & \multicolumn{3}{|c|}{ m.a.t di Permukaan } \\
\hline & $5 \mathrm{Mw}$ & $6,3 \mathrm{Mw}$ & $8,1 \mathrm{Mw}$ & $5 \mathrm{Mw}$ & $6,3 \mathrm{Mw}$ & $8,1 \mathrm{Mw}$ \\
\hline $\mathrm{S} 4$ & 7,9 & 8,6 & 8,9 & 19,4 & 19,5 & 19,7 \\
\hline S5 & 6,1 & 7,3 & 8,0 & 14,9 & 15,6 & 16,2 \\
\hline S6 & 6,1 & 7,2 & 7,3 & 14,0 & 14,4 & 14,6 \\
\hline S7 & 3,7 & 6,2 & 6,7 & 12,9 & 13,3 & 13,6 \\
\hline
\end{tabular}

Berdasarkan taksiran nilai penurunan tanah yang terjadi, direkomendasikan;

1. Untuk fondasi tiang, tahanan friksi pada lapisan tanah $0-6$ meter harus diabaikan dalam desainnya.

2. Penggunaan fondasi dangkal tidak direkomendasikan pada kawasan pesisir pantai Kabupaten Kulon Progo DIY, kecuali dilakukan metode perbaikan tanah untuk menghilangkan potensi likuefaksi.

\section{KESIMPULAN DAN SARAN}

Kesimpulan pada potensi likuefaksi berdasarkan data CPT di Kabupaten Kulon Progo DIY adalah sebagai berikut:

- Lapisan tanah di kedalaman lapisan 0 - 6 meter berada pada kategori tidak aman terhadap potensi bahaya likuefaksi. Untuk antisipasi bahaya likuefaksi pada bangunan gedung, pembangunan konstruksi fondasi disarankan memiliki kedalaman melebihi 6 meter.

- Kawasan pesisir pantai di Kabupaten Kulon Progo DIY berpotensi sangat tinggi mengalami likuefaksi pada gempa dengan skala magnitudo $\geq 6,3 \mathrm{Mw}$.

- Penurunan maksimum ditaksir mencapai $19,7 \mathrm{~cm}$ terjadi pada magnitudo $8,1 \mathrm{Mw}$ dengan kondisi muka air tanah di permukaan. Penggunaan fondasi dangkal di kedalaman lapisan tanah $0-6$ meter tidak direkomendasikan, kecuali dilakukan metode perbaikan tanah untuk menghilangkan potensi likuefaksi.

Analisis likuefaksi terbatas pada kawasan pesisir pantai di Kabupaten Kulon Progo DIY. Saran berupa gagasan supaya analisis likuefaksi diterapkan di seluruh wilayah Indonesia. Hal ini akan sangat berguna sebagai ilmu pengetahuan di bidang geoteknik mengenai daerah yang bahaya terhadap potensi likuefaksi, sehingga dapat diperhitungkan untuk desain pondasi yang aman terhadap penurunan.

\section{DAFTAR PUSTAKA}

Ahmed, S. M. (2017). Correlating The Shear Wave Velocity With The Cone Penetration Test. doi:https://doi.org/10.11159/icgre17.155

Boulanger, R. W., \& Idriss, I. M. (2014). CPT And SPT Based Liquefaction Triggering Procedures.

Dixit, J. e. a. (2012). Assessment Of Liquefaction Potential Index For Mumbai City. 2759-2768. doi:https://doi.org/10.5194/nhess-12-2759-2012

Iwasaki, e. a. (1978). A Practical Method For Assessing Soil Liquefaction Potential Based On Case Studies At Various Sites In Japan. Proc., 2nd Int. Conf. on Microzonation, San Francisco, 885-896.

Luna, R., \& Frost, J. D. (1998). Spatial Liquefaction Analysis System. J. Comput. Civil Eng, 12, 48-56.

Meisina, C. e. a. (2017). Differences Between Mechanical And Electrical Cone Penetration Test In The Liquefaction Hazard Assessment And Soil Profile Reconstruction.

Meyerhof, G. G. (1956). Penetration Test And Bearing Capacity Of Cohesionless Soils. Journal of the Soil Mechanics and Foundation Division, ASCE, 82(1), 1-19.

Nasional, B. S. (2008). Standar Perencanaan Ketahanan Gempa Untuk Jembatan. 
Nasional, B. S. (2012). Tata Cara Perencanaan Ketahanan Gempa Untuk Struktur Bangunan Gedung Dan Non Gedung.

Robertson, P. K., \& Cabal, K. L. (2010). Estimating Soil Unit Weight From CPT.

Wair, e. a. (2012). Guidelines For Estimation Of Shear Wave Velocity Profiles. Pacific Earthq. Eng, 8, 68.

Zhang, e. a. (2002). Estimating Liquefaction-induced Ground Settlements From CPT For Level Ground. 1168-1180. doi:https://doi.org/10.1139/T02-047 